\title{
Profiles of hemodynamics and oxygen transport derived by using continuous measured oxygen consumption after the Norwood procedure
}

Jia Li, MD, PhD, Gencheng Zhang, MD, PhD, Brian W. McCrindle, MD, MPH, Helen Holtby, MBBS, Tilman Humpl, MD, Sally Cai, MS, Christopher A. Caldarone, MD, Andrew N. Redington, MD, and Glen S. Van Arsdell, MD

Supplemental material is available online.
From the Cardiac Program, the Hospital for Sick Children, Toronto, Ontario, Canada.

Supported by the Heart and Stroke Foundation of Canada (JL and ANR) and the Canadian Institute of Health Research (JL, ANR, CC, and GSV).

Received for publication May 5, 2006; revisions received Aug 11, 2006; accepted for publication Sept 6, 2006.

Address for reprints: Glen S. Van Arsdell, MD, Division of Cardiovascular Surgery, The Hospital for Sick Children, 555 University Ave, Toronto, Ontario, Canada M5G 1X8 (E-mail: glen.vanarsdell@ sickkids.ca). J Thorac Cardiovasc Surg 2007;133:441-8 $0022-5223 / \$ 32.00$

Copyright $\odot 2007$ by The American Association for Thoracic Surgery

doi:10.1016/j.jtcvs.2006.09.033
Objectives: The lack of accurate measurement of hemodynamics and oxygen transport has limited our understanding of Norwood physiology and postoperative management. We used measured oxygen consumption to characterize hemodynamics and oxygen transport after the classic Norwood procedure.

Methods: Fourteen neonates had continuous respiratory mass spectrometry to measure oxygen consumption $\left(\mathrm{VO}_{2}\right)$. Arterial, superior vena caval, and pulmonary venous saturations were measured at 2- to 4-hour intervals for 72 hours postoperatively. Systemic (Qs) and pulmonary (Qp) blood flows, systemic vascular resistance (SVR) and pulmonary vascular resistance inclusive of the Blalock-Taussig shunt (BTPVR), systemic oxygen delivery $\left(\mathrm{DO}_{2}\right)$, and the oxygen extraction ratio $\left(\mathrm{ERO}_{2}\right)$ were calculated.

Results: Qs and $\mathrm{DO}_{2}$ were low during the first 12 hours $\left(1.8 \pm 0.6 \mathrm{~L} \cdot \mathrm{min}^{-1} \cdot \mathrm{m}^{-2}\right.$ and $281 \pm 86 \mathrm{~mL} \cdot \mathrm{min}^{-1} \cdot \mathrm{m}^{-2}$ at the 12 th hour, respectively) and increased over the study period $\left(P<.05\right.$ for both). $\mathrm{VO}_{2}$ decreased markedly during the first 24 hours $\left(101 \pm 26\right.$ to $\left.86 \pm 16 \mathrm{~mL} \cdot \mathrm{min}^{-1} \cdot \mathrm{m}^{-2}, P<.0001\right)$. Consequently, $\mathrm{ERO}_{2}$ decreased significantly over the study, most rapidly during the first 24 hours $(0.44$ \pm 0.11 to $0.28 \pm 0.09, P<.0001)$. There was a close correlation of $\mathrm{DO}_{2}$ to $\mathrm{SVR}$ and to Qs $\left(P<.0001\right.$ for both). There was no correlation of $\mathrm{DO}_{2}$ to BT-PVR $(P=$ $.14)$ or to $\mathrm{Qp}(P=.67) . \mathrm{DO}_{2}$ was closely correlated with hemoglobin value $(P<$ $.0001)$, weakly correlated with $\mathrm{PaO}_{2}(P=.0002)$, and not correlated with arterial oxygen saturation $(P=.32)$.

Conclusions: There is wide variability of hemodynamics and oxygen transport after the Norwood procedure. The decrease in $\mathrm{VO}_{2}$ during the first 24 hours is the main contributor to improving the balance of oxygen transport. $\mathrm{DO}_{2}$ is most closely correlated to SVR and hemoglobin and weakly correlated to $\mathrm{PaO}_{2}$. It is not correlated to Qp. Postoperative management strategies to decrease $\mathrm{VO}_{2}$ and maintain a high hemoglobin level and a low SVR appear to be rational.

$\mathrm{T}$ The Norwood procedure for hypoplastic left heart syndrome and its similar anatomic variants continues to have significant morbidity and a mortality that ranges from $6 \%$ to $25 \% .^{1,2}$ Despite advances in surgical and postoperative management, these infants have little hemodynamic reserve. Instability after repair is inherent to the single ventricle supplying parallel pulmonary and systemic circulations and is compounded by the variable effects of cardiopulmonary bypass $(\mathrm{CPB})$ and ischemia and reperfusion injury. As a result, the marginal systemic oxygen delivery $\left(\mathrm{DO}_{2}\right)$ is dependent on a balance between pulmonary blood flow (Qp) and systemic blood flow (Qs). A number of theoretic studies, ${ }^{3,4}$ clinical studies, ${ }^{5}$ and experimental models ${ }^{6}$ have been reported analyzing the effect of manipulation of Qp or Qs and its relationship to $\mathrm{DO}_{2}$. Previous human 

Abbreviations and Acronyms
BT-PVR = pulmonary vascular resistance inclusive of the Blalock-Taussig shunt
$\mathrm{CO}=$ cardiac output
$\mathrm{CPB}=$ cardiopulmonary bypass
$\mathrm{DO}_{2}=$ systemic oxygen delivery
$\mathrm{ERO}_{2}=$ oxygen extraction ratio
$\mathrm{Hb} \quad=$ hemoglobin
Qp = pulmonary blood flow
Qs $\quad=$ systemic blood flow
SVR = systemic vascular resistance
$\mathrm{VO}_{2}=$ oxygen consumption

\section{Materials and Methods \\ Patients}

This study was approved by the Research Ethics Board at the Hospital for Sick Children, Toronto, Canada. Written informed consent was obtained from the parents of 14 neonates (11 boys and 3 girls; age range, 4-16 days; median, 7 days) undergoing the Norwood procedure between April 2004 and January 2006. Some of these patients were included in other reports. ${ }^{12,16}$ The clinical characteristics of the patients are shown in Table E1. Patients excluded from this study were those having an alternative strategy for palliation of hypoplastic left heart syndrome. During this time frame, 3 patients undergoing a conventional Norwood procedure were not offered the study because of reasons pertaining to equipment or technical support availability.

\section{Operative Procedure}

Patients were intubated with a cuffed endotracheal tube (MicrocuffHeidelberg-Pediatric; Microcuff $\mathrm{GmbH}$, Weinheim, Germany). General anesthesia was maintained with inhaled isoflurane, intravenous fentanyl, and pancuronium bromide. A standard Norwood procedure with a preference for regional cerebral circulation was used. ${ }^{17}$ All patients had a 3.5-mm right modified Blalock-Taussig shunt, with the distal anastomosis placed centrally on the intramediastinal pulmonary artery. CPB was maintained for 66 to 172 minutes (median, 133 minutes), and an aortic crossclamp was maintained for 38 to 126 minutes (median, 62 minutes). Circulatory arrest was performed for 1 to 46 minutes (median, 12 minutes), and selected cerebral perfusion was performed in 13 of 14 patients for 20 to 70 minutes (median, 53 minutes) at 30 to $35 \mathrm{~mL} \cdot \mathrm{min}^{-1} \cdot \mathrm{kg}^{-1}$ (Table E1). Phenoxybenzamine, $0.25 \mathrm{mg} / \mathrm{kg}$, was given in the heart-lung machine circuit after initiation of CPB. A bolus of $50,000 \mathrm{KIU}$ of aprotinin was administered, followed by 100,000 $\mathrm{KIU}$ per $100 \mathrm{~mL}$ of prime. Before termination of $\mathrm{CPB}$, milrinone $(100 \mu \mathrm{g} / \mathrm{kg})$ was administered, and dopamine $\left(5 \mu \mathrm{g} \cdot \mathrm{kg}^{-1} \cdot \mathrm{min}^{-1}\right)$ was initiated. A pulmonary venous line was inserted into the orifice of the right upper pulmonary vein. A direct oximetric line (Abbott Critical Care Systems, Abbott Laboratories, Chicago, Ill) was inserted in the superior vena cava.

\section{Critical Care}

Infants received time-cycled volume ventilation with pressure support. Sedation was obtained with a continuous intravenous infusion of morphine $\left(20-40 \mu \mathrm{g} \cdot \mathrm{h}^{-1} \cdot \mathrm{kg}^{-1}\right)$ and intermittent injections of a muscle relaxant (pancuronium, $0.1 \mathrm{mg} / \mathrm{kg}$ ) and lorazepam $(0.1$ $\mathrm{mg} / \mathrm{kg}$ ). Pancuronium was discontinued when the patient achieved satisfactory hemodynamic stability.

The central temperature was maintained at $36^{\circ} \mathrm{C}$ to $37^{\circ} \mathrm{C}$. Inotropic and vasoactive agents (milrinone, dopamine, phenoxybenzamine, and vasopressin) and ventilatory settings (the minute ventilation volume/rate) were adjusted according to our standard protocol, with an inspiratory oxygen fraction at or close to 0.21 (mean arterial blood pressure of $40-45 \mathrm{~mm} \mathrm{Hg}$ with systolic pressure in the range of 55-65 $\mathrm{mm} \mathrm{Hg}$, arterial oxygen saturation of $70 \%-80 \%$, and superior vena caval saturation of $44 \%-55 \%){ }^{18}$ Inspired oxygen was titrated upward for saturation of less than $70 \%$. Volume infusions (5\% albumin or blood) were given to maintain filling pressures of 7 to $10 \mathrm{~mm} \mathrm{Hg}$. Transfusions were 
given for a hemoglobin $(\mathrm{Hb})$ value of less than $14 \mathrm{mg} / \mathrm{dL}$, and the $\mathrm{Hb}$ value was generally maintained between 14 and $16 \mathrm{mg} / \mathrm{dL}$.

\section{Methods of Measurement}

Patient monitoring. All patients had continuous invasive monitoring of systemic, superior vena caval, and pulmonary venous pressures. Continuous monitoring of superior vena caval $\mathrm{O}_{2}$ saturation was used, as was heart rate and central body temperature (esophageal).

$\boldsymbol{V O}_{2} \cdot \mathrm{VO}_{2}$ was measured continuously by using an AMIS2000 mass spectrometer (Innovision A/S, Odense, Denmark). This is a sensitive and accurate method for continuous gas analysis that allows simultaneous measurements of multiple gas fractions. ${ }^{19}$

Calculations of hemodynamics and oxygen transport. Blood samples were taken from the arterial superior vena cava, and pulmonary venous lines for the measurements of blood gases. Qp and Qs were then calculated by using the direct Fick method. Total cardiac output (CO), $\mathrm{DO}_{2}$, systemic vascular resistance (SVR), pulmonary vascular resistance inclusive of the Blalock-Taussig shunt (BT-PVR), and $\mathrm{ERO}_{2}$ were calculated by using standard equations (Table E2).

\section{Study Protocol}

This study was performed during the first 72 hours after arrival in the intensive care unit (ICU). Values of hemodynamics, oxygen transport, and central body temperature were collected at 2-hour intervals during the first 24 hours and at 4-hour intervals from hours 25 through 72 .

\section{Data Analysis}

Data are expressed as means \pm standard deviation. Simple linear regression was used to determine correlations between preoperative (age, weight, and body surface area) and intraoperative demographics (duration of CPB, aortic crossclamp time, total circulatory arrest, or partial circulatory arrest with regional cerebral perfusion) and the first postoperative hemodynamic and oxygen transport measures. The comparison of intraindividual variations between 2 data sets was performed by using the Hartley F-max method. Mixed linear regression analysis for repeated measures was used to determine the nature of any time trend of the measures over the 72-hour study period. For some measures, various transformations of time (logarithmic and polynomial) were tested regarding the best fit for the time course. Interrelationships among the measures were sought by using mixed linear regression analysis for repeated measures without regard to time. Logarithmic transformation of both variables being compared was used when necessary to model nonlinear relationships. The extent of change and correlation was indicated by the intercept and parametric estimate. All data analysis was performed with SAS statistical software version 8 (SAS Institute, Inc, Cary, NC).

\section{Results}

Patients

There were no deaths and no episodes of circulatory collapse during the study period. One patient required extracorporeal membrane oxygenation support subsequent to the study period. Patients were extubated between 4 and 25 days (median, 10 days). All patients survived to hospital discharge. Milrinone $\left(0.33-0.99 \mu \mathrm{g} \cdot \mathrm{min}^{-1} \cdot \mathrm{kg}^{-1}\right)$ was used in all the patients throughout the study period. Dopamine $\left(5-10 \mu \mathrm{g} \cdot \min ^{-1} \cdot \mathrm{kg}^{-1}\right)$ was initiated before the termination of CPB in all patients and subsequently stopped within the first 24 hours after arrival in the ICU in 13 patients; it was used for the entire study period in the remaining patient. Additional intravenous phenoxybenzamine $\left(0.5-2.0 \mathrm{mg} \cdot \mathrm{day}^{-1} \cdot \mathrm{kg}^{-1}\right)$ was commenced within the first 10 hours and continued for the rest of the study period in 12 of 14 patients. Vasopressin (0.0001-0.0005 $\mathrm{U} \cdot \mathrm{min}^{-1} \cdot \mathrm{kg}^{-1}$ ) was administered to 10 patients at different times for 10 to 60 hours during the study period. Two patients had primary sternal closure. Delayed sternal closure was performed on the remainder on postoperative days 3 to 6 , with 1 outlier occurring at day 17 .

\section{Profiles of Hemodynamics and Oxygen Transport}

Table E3 shows the results for the trends of central body temperature, hemodynamics, oxygen transport, arterial oxygenation, and $\mathrm{Hb}$ value.

Baseline measures. On arrival to the ICU, central body temperature was $35.9^{\circ} \mathrm{C} \pm 0.8^{\circ} \mathrm{C}$. Total $\mathrm{CO}$ was $4.1 \pm 1.4$ $\mathrm{L} \cdot \mathrm{min}^{-1} \cdot \mathrm{m}^{-2}$, with an SVR of $24.0 \pm 13.8$, a BT-PVR of $17.6 \pm 5.5$ Wood unit $/ \mathrm{m}^{2}$, and a Qp/Qs ratio of $1.4 \pm 0.7$. Qp was $2.2 \pm 0.8 \mathrm{~L} \cdot \mathrm{min}^{-1} \cdot \mathrm{m}^{-2}$, and Qs was $1.9 \pm 1.0$ $\mathrm{L} \cdot \mathrm{min}^{-1} \cdot \mathrm{m}^{-2}$. The $\mathrm{Hb}$ value was $14.3 \pm 42.7 \mathrm{~g} / \mathrm{dL}$, and $\mathrm{DO}_{2}$ was $251 \pm 111 \mathrm{~mL} \cdot \mathrm{min}^{-1} \cdot \mathrm{m}^{-2}$. VO 2 was $101 \pm 26$ $\mathrm{mL} \cdot \min ^{-1} \cdot \mathrm{m}^{-2} \cdot \mathrm{ERO}_{2}$ was $0.44 \pm 0.11$. The arterial blood lactate level was $5.5 \pm 2.2 \mathrm{mmol} / \mathrm{L}$.

None of the initial oxygen transport and hemodynamic values were correlated with age, body weight, and body surface area $(P<.05$ for all). None of the operative variables (duration of $\mathrm{CPB}$, aortic crossclamping, circulatory arrest, or regional cerebral perfusion time) correlated with the initial measured postoperative characteristics $(P>.05$ for all).

Oxygen transport changes during the study period. All the studied hemodynamic and oxygen transport measures showed substantial interindividual variations over the study period. The time course and the extent of changes in hemodynamic and oxygen transport measures also varied greatly (Table E3 and Figure 1).

LONGITUDINAL TRENDS OF SVR, Qs, CO, BT-PVR, AND QP. There were wide variations within individual patients with respect to SVR, Qs, CO, and Qp/Qs ratio. BT-PVR did not change significantly over time $(P>.05)$, but Qp showed a small and significant increase over time $(P<.0001)$. SVR, Qs, and CO were related to time in a complex polynomial function, with an early decrease in $\operatorname{SVR}(P=.0006)$ and an increase in Qs $(P<.0001)$ and $\mathrm{CO}(P=.001)$ peaking around 28 to 32 hours, followed by a slow increase in $\operatorname{SVR}(P=.001)$ and a decrease in Qs and $\mathrm{CO}(P<.0001$ 

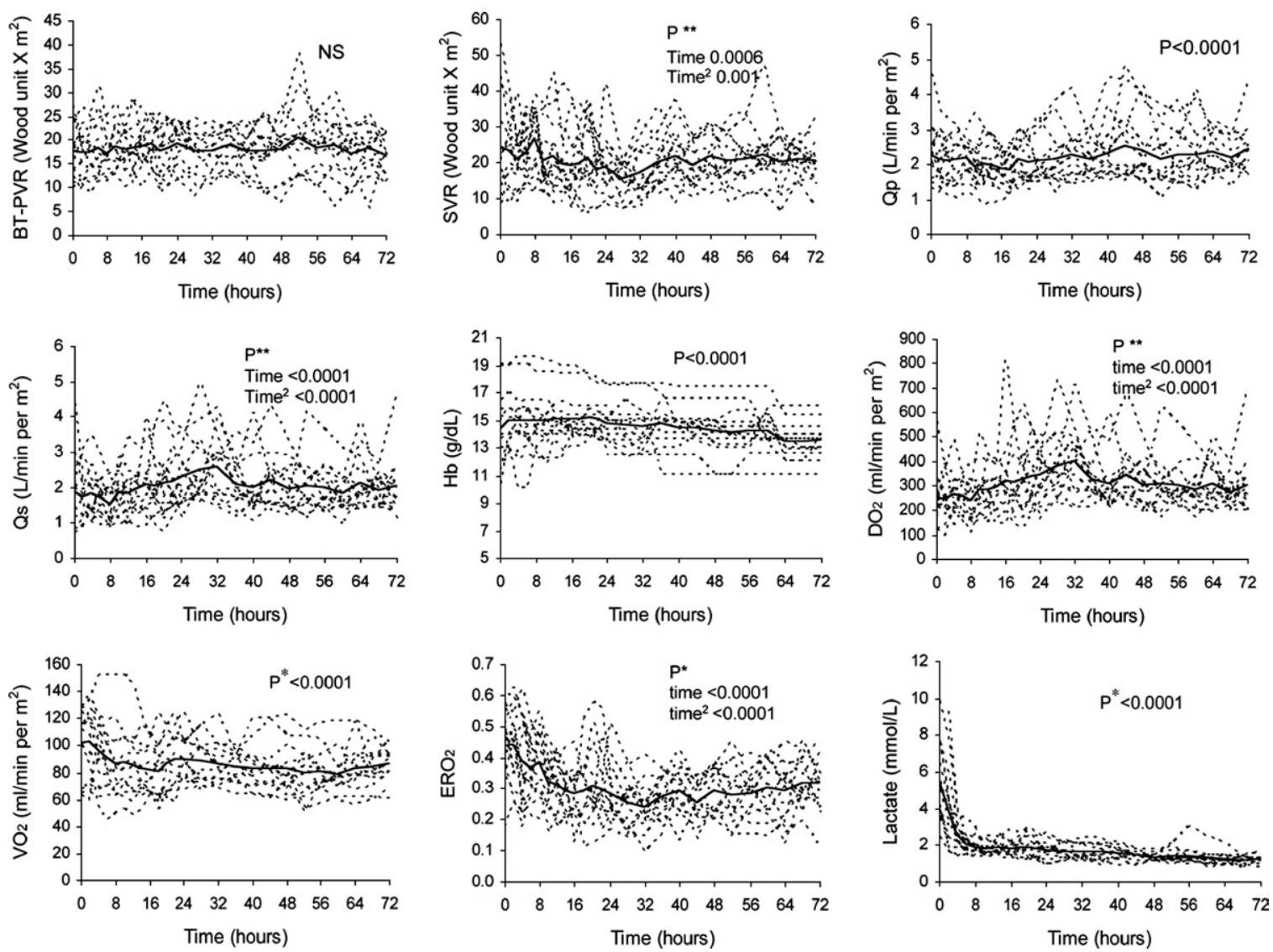

Figure 1. Individual and mean values of main variables of hemodynamics and oxygen transport, including total pulmonary vascular resistance inclusive of the resistance of the Blalock-Taussig shunt (BT-PVR) and systemic vascular resistance (SVR), pulmonary ( $Q p$ ) and systemic $(\mathrm{Os})$ blood flows, hemoglobin value (Hb), oxygen delivery $\left(\mathrm{DO}_{2}\right)$, oxygen consumption $\left(\mathrm{VO}_{2}\right)$, oxygen extraction ratio $\left(E R \mathrm{O}_{2}\right)$, and arterial lactate levels during the first 72 hours after arrival in the ICU. *Data were entered after logarithmic transformation. **Data were entered after polynomial transformation, with time indicating the parametric estimate of the early trend and time $^{2}$ indicating the later trend.

for Qs and $P=.025$ for $\mathrm{CO}$ ). Qs and CO were significantly lower during the first 24 hours compared with that seen during the subsequent 48 hours $(P<.0001$ for Qs and $P=$ .0004 for $\mathrm{CO}$ ). A comparison of the first 24 hours and subsequent 48 hours showed no change in $\mathrm{Qp}$. There was no change over time for $\mathrm{Qp} / \mathrm{Qs}$ ratio $(P>.05)$.

LONGITUDINAL TRENDS IN TEMPERATURE OF $\mathrm{VO}_{2}$ AND $\mathrm{DO}_{2}$. Central temperature did not change significantly during the study period $(P>.05)$, except for the initial significant increase during the first 2 hours after arrival in the ICU $(P=.005) . \mathrm{VO}_{2}$ was significantly related to time after logarithmic transformation and showed a rapid decrease in the first 24 hours $(P<.0001)$. There were wide interindividual and intraindividual fluctuations. Total $\mathrm{VO}_{2}$ range was from 45 to $152 \mathrm{~mL} \cdot \mathrm{min}^{-1} \cdot \mathrm{m}^{-2} \cdot \mathrm{DO}_{2}$ was significantly related to time in a complex polynomial function, with an early increase peaking around 28 to 36 hours $(P<.0001)$, followed by a slow decrease $(P<.0001)$. Wide variations were noted within individuals.

$\mathrm{ERO}_{2} . \mathrm{ERO}_{2}$ was significantly related to time in a complex polynomial function, with an initial rapid decrease in the first 24 hours, followed by a slow decrease $(P<.0001)$ and a subsequent small but significant increase at 48 hours $(P<.0001)$.

ARTERIAL SERUM LACTATE. Lactate levels were significantly related to time after logarithmic transformation and showed an initial rapid decrease in the first 6 hours, followed by a slower steady decrease $(P<.0001)$.

LONGITUDINAL TRENDS IN CONTRIBUTORS TO ARTERIAL $\mathrm{O}_{2}$ CONTENT. There was a small but significant increase in pulmonary venous $\mathrm{O}_{2}$ saturation over time $(P<.0001)$. Both $\mathrm{PaO}_{2}$ and arterial oxygen saturation $\left(\mathrm{SaO}_{2}\right)$ were significantly related to time after logarithmic transformation, with a fast increase in the first 24 hours, followed by a slow increase $(P<.0001$ for both). Hb value showed a small significant linear decrease over time $(P<.0001)$. Arterial 

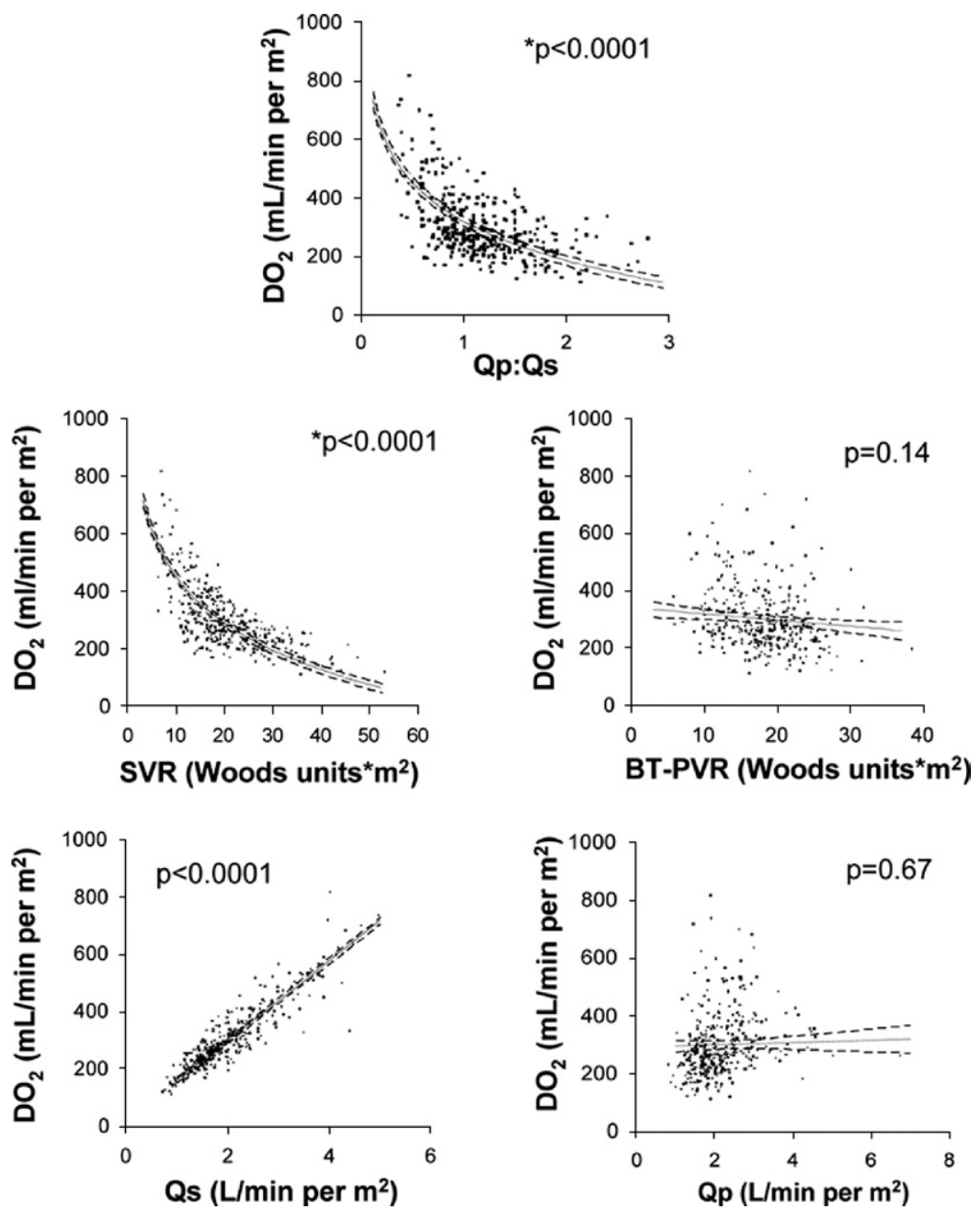

$\mathrm{O}_{2}$ content was related to time in a complex polynomial function, with an early increase in the first 10 hours $(P=$ $.004)$, followed by a slow decrease $(P=.0009)$. Of note, pulmonary venous $\mathrm{O}_{2}$ saturation was less than $95 \%$ in $40 \%$ of the total sample times (140/350).

\section{Interrelationships Among the Variables}

The statistical results of the interrelationships among the variables using mixed linear regressions are seen in Table E4 and Figure 2. The extent of the correlation is indicated by the intercept and coefficient values.

$\boldsymbol{S V R}$. Over the entire study period, SVR was linearly and highly positively correlated with $\mathrm{Qp} / \mathrm{Qs}$ ratio and nonlinearly negatively correlated with $\mathrm{Qs}, \mathrm{CO}$, and $\mathrm{DO}_{2}$ (after logarithmic transformation, $P<.0001$ for all).

$\boldsymbol{B T}$-PVR. BT-PVR was significantly negatively and linearly correlated with $\mathrm{Qp} / \mathrm{Qs}$ ratio $(P=.002)$ and $\mathrm{CO}(P<$ .0001) and nonlinearly with Qp (after logarithmic transformation, $P<.0001$ ). The influence of BT-PVR on Qp/Qs ratio, Qs, and CO was not as strong as that seen with SVR,
Figure 2. Correlations between hemodynamic variables of pulmonary/systemic blood flow ratio $(0 p / 0 s)$, systemic vascular resistance (SVR), systemic blood flow (Qs), total pulmonary vascular resistance inclusive of the Blalock-Taussig shunt (BT-PVR), pulmonary blood flow ( $2 p)$, and systemic oxygen delivery $\left(\mathrm{DO}_{2}\right)$ in patients during the first 72 hours after arrival in the ICU. *Data were entered after logarithmic transformation. as demonstrated by the difference in the intercept and parameter estimates in Table E4. There was a weak correlation of BT-PVR with Qs $(P=.008)$ but not $\mathrm{DO}_{2}(P=.14)$.

$Q p / Q s$ ratio. The $\mathrm{Qp} / \mathrm{Qs}$ ratio was significantly $(P<$ .001) affected by both Qs and Qp; however, Qs showed a stronger correlation, as seen by the difference in the intercept and coefficient in Table E4.

$\mathbf{D O}_{2}$. There was a close linear correlation of $\mathrm{DO}_{2}$ with Qs $(P<.0001)$ but not with Qp $(P=.67) . \mathrm{DO}_{2}$ was significantly and nonlinearly negatively correlated with Qp/Qs ratio (after logarithmic transformation, $P<.0001$ ).

Arterial $\mathrm{O}_{2}$ content and $\mathbf{D O}_{2}$. Qp had a weak positive correlation with $\mathrm{SaO}_{2}$ and $\mathrm{PaO}_{2}\left(P<.0001\right.$ for both). $\mathrm{PaO}_{2}$ had a weak positive correlation with $\mathrm{DO}_{2}(P=.0002)$. There was no correlation of $\mathrm{SaO}_{2}$ with $\mathrm{DO}_{2}(P=.32)$. Inclusion of $\mathrm{SaO}_{2}$, $\mathrm{PaO}_{2}, \mathrm{Hb}$ value, and Qs showed that $\mathrm{SaO}_{2}$ and $\mathrm{PaO}_{2}$ were positively but weakly correlated with $\mathrm{DO}_{2}\left(P<.0001\right.$ for $\mathrm{SaO}_{2}$ and $P=.002$ for $\left.\mathrm{PaO}_{2}\right)$. $\mathrm{Hb}$ value had a high positive correlation with $\mathrm{DO}_{2}(P<.0001)$. 
$\boldsymbol{E R O}_{2} \cdot \mathrm{ERO}_{2}$ had a close positive correlation with $\mathrm{VO}_{2}$ and a negative correlation with $\mathrm{DO}_{2}(P<.0001$ for both).

\section{Discussion}

This study examines detailed quantitative assessments of hemodynamics and oxygen transport after the Norwood procedure, where $\mathrm{VO}_{2}$ and pulmonary venous $\mathrm{O}_{2}$ saturations were not assumed. Measurement of $\mathrm{VO}_{2}$; superior vena caval, arterial, and pulmonary venous pressures; and blood gases allows calculation of Qp and Qs. Total CO, Qp/Qs ratio, SVR, BT-PVR, $\mathrm{DO}_{2}$, and $\mathrm{ERO}_{2}$ can then be calculated. Previous studies used assumptions for $\mathrm{VO}_{2}$ in the range of 160 to $180 \mathrm{~mL} \cdot \mathrm{min}^{-1} \cdot \mathrm{m}^{-2}$ to calculate hemodynamics. ${ }^{7,8,10}$ Those assumptions are much higher than what was observed in our patients (range, 45-152 $\mathrm{mL} \cdot \mathrm{min}^{-1} \cdot \mathrm{m}^{-2}$; mean at arrival in the ICU, $101 \mathrm{~mL}$. $\mathrm{min}^{-1} \cdot \mathrm{m}^{-2}$ ). Overestimation of $\mathrm{VO}_{2}$ leads to a direct proportional change in the estimation for the calculated variables. For example, an assumed $\mathrm{VO}_{2}$ of $170 \mathrm{~mL} \cdot \mathrm{min}^{-1} \cdot \mathrm{m}^{-2}$ compared with the measured mean $\mathrm{VO}_{2}$ on arrival to the ICU of $101 \mathrm{~mL} \cdot \mathrm{min}^{-1} \cdot \mathrm{m}^{-2}$ would lead to a $68 \%$ overestimation of total CO, Qp, and Qs and a 68\% underestimation of PVR and SVR. Taeed and colleagues ${ }^{13}$ previously noted the occurrence of pulmonary venous $\mathrm{O}_{2}$ desaturation after the Norwood procedure. We found pulmonary venous desaturation (defined as $<95 \%$ saturation) in $40 \%$ of the pulmonary venous samples taken. The effect of a falsely high assumption of pulmonary venous saturation can be seen in the following example from one of our observed patients: measured pulmonary venous saturation was $90 \%$, and an assumed pulmonary venous saturation of 96\% would have lead to an underestimation of Qp by 35\% and therefore the Qp/Qs ratio by $35 \%$ as well. The data demonstrate that continuous $\mathrm{VO}_{2}$ and measured pulmonary venous $\mathrm{O}_{2}$ saturation have a significant effect on the calculated variables and therefore potential for having an effect on management strategy.

\section{Cardiac Output and Characteristics of Qp and Qs}

The single ventricle is subject to considerable demand for total $\mathrm{CO}$. There is great variation both individually and within the cohort (total range, $1.9-8.3 \mathrm{~L} \cdot \mathrm{min}^{-1} \cdot \mathrm{m}^{-2}$; mean range, 3.7-4.9 $\mathrm{L} \cdot \min ^{-1} \cdot \mathrm{m}^{-2}$ ). On an individual basis, the Qp/Qs ratio was highly variable $(0.35-2.8)$ but on a mean basis, it was less varied for 0.9 to 1.5 . On analysis, SVR was tightly correlated with the Qp/Qs ratio and negatively correlated with $\mathrm{Qs}, \mathrm{CO}$, and $\mathrm{DO}_{2}$. BT-PVR was negatively correlated with the Qp/Qs ratio, $\mathrm{CO}$, and Qp, but this was a weaker correlation than with SVR. In other words, SVR was far more important in determining the balance of the Qp/Qs ratio than was BT-PVR. SVR was also significantly more variable than BT-PVR, despite the use of $\alpha$ blockade and phosphodiesterase inhibitors. These find- ings are important because, historically, the postoperative management strategy of patients undergoing the Norwood procedure was directed at diminishing Qp by increasing PVR. ${ }^{5,20,21}$ More recently, some, including us, have advocated aggressive reduction of SVR as a primary management strategy. This has resulted in improved outcomes for those who have reported the strategy. ${ }^{10,18,22}$ In the presence of aggressive afterload reduction, it has been thought that PVR was relatively fixed. ${ }^{10,11}$ The findings of this study indicate that both the systemic and pulmonary vascular compartments have variable resistance, but the systemic circulation has a more profound effect on the balance of the Qp/Qs ratio. SVR also has an effect on Qs and total CO. Although the study does not address the ability of ventilation and oxygenation strategy to alter BT-PVR, a rational clinical approach would appear to be a combined approach of ventilation strategies to increase BT-PVR (additional inspired $\mathrm{CO}_{2}$ ) plus effective afterload reduction. Both would promote an improved Qp/Qs ratio and increased Qs and therefore improved $\mathrm{DO}_{2}$. Interestingly, increasing $\mathrm{PaO}_{2}$ had only a weak positive correlation with $\mathrm{Qp}$, implying that relative hypoxia yields little benefit to the balance of the Qp/Qs ratio.

\section{Contribution of $\mathrm{VO}_{2}$ to the Balance of Oxygen Transport}

Matching $\mathrm{DO}_{2}$ to $\mathrm{VO}_{2}$ is one of the tenets of care in critically ill patients. ${ }^{15,19,23,24}$ The first 24-hour improvement seen in this group of patients in $\mathrm{ERO}_{2}$ and arterial lactate levels occurred when $\mathrm{CO}, \mathrm{Qs}$, and $\mathrm{DO}_{2}$ were most decreased. The data demonstrate that the main early contributor to the improved $\mathrm{ERO}_{2}$ was decreasing $\mathrm{VO}_{2}$.

$\mathrm{VO}_{2}$ can be increased after $\mathrm{CPB}$ as a consequence of rewarming ${ }^{15,19,25}$ and the systemic inflammatory response. ${ }^{15,26}$ After arrival in the ICU, there was a continuous but biphasic decrease in $\mathrm{VO}_{2}$ in the presence of normothermia. A more rapid decrease occurred for 24 hours, followed by a slower decrease for the following 48 hours. After 24 hours, $\mathrm{DO}_{2}$ became the primary contributor to the balance of $\mathrm{DO}_{2}$ and $\mathrm{VO}_{2}$.

Another important issue with respect to $\mathrm{VO}_{2}$ is the potential effect of vasoactive and inotropic agents. In a neonatal lamb model the use of $\beta$-sympathomimetic drugs was associated with a rapid and substantial increase in $\mathrm{VO}_{2}$, offsetting the benefits of increased $\mathrm{DO}_{2} \cdot{ }^{24}$ Our routine is to terminate $\mathrm{CPB}$ on $5 \mu \mathrm{g} \cdot \mathrm{min}^{-1} \cdot \mathrm{kg}^{-1}$ dopamine but to subsequently discontinue its use in the ICU to try to decrease myocardial oxygen demand. Cessation of dopamine might have contributed to the decrease in $\mathrm{VO}_{2}$ in the first 24 hours in the ICU. ${ }^{16}$ The introduction of $\alpha$ blockade might also be important in this regard. Animal data suggest that inhibition of $\alpha$ stimulation in brown fat tissue might reduce the metabolic rate. ${ }^{27}$ Further studies might be warranted to directly quantitatively assess the effects of inotropes and 
vasoactive drugs on $\mathrm{VO}_{2}$ and $\mathrm{DO}_{2}$ in these patients, while controlling for other variables that might affect $\mathrm{VO}_{2}$.

\section{Optimizing Oxygen Delivery}

Systemic $\mathrm{DO}_{2}$ mean values were $281 \pm 86 \mathrm{~mL} \cdot \min ^{-1} \cdot \mathrm{m}^{-2}$ at the 12 th hour after the Norwood procedure. Although there were significant interindividual and intraindividual variations throughout the study, these values are low in comparison with our studies of complete repair for congenital heart defects in older children $(281 \pm 86$ vs $368 \pm 94$ $\left.\mathrm{mL} \cdot \mathrm{min}^{-1} \cdot \mathrm{m}^{-2}\right) \cdot{ }^{15} \mathrm{DO}_{2}$ is limited by the effects of common mixing and low Qs $\left(1.8 \pm 0.6 \mathrm{~L} \cdot \mathrm{min}^{-1} \cdot \mathrm{m}^{-2}\right){ }^{28,29}$ The variables for potentially improving $\mathrm{DO}_{2}$ include increasing $\mathrm{SaO}_{2}, \mathrm{PaO}_{2}$, and $\mathrm{Hb}$ value; altering the $\mathrm{Qp} / \mathrm{Qs}$ ratio; and absolutely increasing total CO. Our analysis demonstrated that within the ranges of $\mathrm{SaO}_{2}$ and $\mathrm{PaO}_{2}$ observed, there was only weak correlation with $\mathrm{DO}_{2}$. There was, however, a tight correlation between $\mathrm{DO}_{2}$ and $\mathrm{Hb}$ value. Our data therefore support the common practice of maintaining the postoperative hematocrit value at greater than $40 \%$.

With respect to the $\mathrm{Qp} / \mathrm{Qs}$ ratio, Barnea and associates ${ }^{4}$ theorized that maximal $\mathrm{DO}_{2}$ occurs at a $\mathrm{Qp} / \mathrm{Qs}$ ratio of less than 1 over a wide range of COs. Our data show that $\mathrm{DO}_{2}$ was closely, negatively, and logarithmically correlated with the $\mathrm{Qp} / \mathrm{Qs}$ ratio within the wide range $(0.35-2.8)$ for our patients. Mean $\mathrm{DO}_{2}$ (for a similar $\mathrm{Hb}$ value) was highest $\left(460 \pm 152 \mathrm{~mL} \cdot \mathrm{min}^{-1} \cdot \mathrm{m}^{-2}\right.$ ) when the Qp/Qs ratio was less than 0.7 and lower $\left(260 \pm 69 \mathrm{~mL} \cdot \mathrm{min}^{-1} \cdot \mathrm{m}^{-2}\right)$ when the $\mathrm{Qp} / \mathrm{Qs}$ ratio was 1.0 or greater. The data suggest that a direct increase in Qs would result in a lower Qp/Qs ratio and therefore a higher $\mathrm{DO}_{2}$. Therefore maintaining a high $\mathrm{Hb}$ value and decreasing the SVR to most effectively optimize the $\mathrm{Qp} / \mathrm{Qs}$ ratio would be most effective in improving $\mathrm{DO}_{2}$.

\section{Limitations}

Superior vena caval blood was used as an estimate of the mixed venous saturation for the calculations of $\mathrm{Qs}$ and $\mathrm{DO}_{2}$. The relative oxygen contents of the superior and inferior venae cavae might differ. ${ }^{30,31}$ Pulmonary venous saturations were obtained from only 1 pulmonary vein. This would not account for regional lung perfusion and ventilation differences in pulmonary vein saturation.

PVR in this study is actually a measure of resistance across the Blalock-Taussig shunt and the pulmonary vasculature. An indwelling pulmonary arterial catheter would be required to directly measure pulmonary arterial pressure to differentiate actual PVR from that including the BlalockTaussig shunt.

Finally, the hemodynamic and oxygen transport measurements were derived by using the common variables of $\mathrm{VO}_{2}$, blood gases, and pressures. Some were calculated from one another; for example, $\mathrm{DO}_{2}$ and SVR were calculated from Qs. This might induce mathematic coupling and therefore affect correlation analysis. ${ }^{32}$ This study does not address oxygen transport for hypoplastic left heart syndrome palliation by using the Sano modification (right ventricle-pulmonary artery conduit).

\section{Inferences and Conclusions}

Measurement of hemodynamics and oxygen transport allowed detailed observation and analysis of the physiology of neonates after the Norwood procedure. There were wide, unstable, interindividual and intraindividual variations. The balance of $\mathrm{VO}_{2}$ and $\mathrm{DO}_{2}\left(\mathrm{ERO}_{2}\right)$ improved significantly in the first 24 hours, primarily as a result of a decreasing $\mathrm{VO}_{2}$. Thereafter, $\mathrm{DO}_{2}$ became the main contributor to the balance of oxygen transport. Within the limits of the parameters measured, $\mathrm{DO}_{2}$ was most affected by SVR, to a lesser extent by $\mathrm{Hb}$ value, and very minimally by $\mathrm{PaO}_{2} . \mathrm{DO}_{2}$ was not affected by the pulmonary circuit resistance or Qp. The finding of minimal variability of contribution in the pulmonary circuit to $\mathrm{DO}_{2}$ indicates that manipulation of the systemic side of the parallel circulation is of greater importance than the pulmonary side. Future strategies should be designed to improve $\mathrm{DO}_{2}$ and its balance with $\mathrm{VO}_{2}$. Specifically, management strategies to maintain a high $\mathrm{Hb}$ value, a low $\mathrm{VO}_{2}$, and a controlled SVR appear to be rational.

\section{References}

1. Ashburn DA, McCrindle BW, Tchervenkov CI, et al. Outcomes after the Norwood operation in neonates with critical aortic stenosis or aortic valve atresia. J Thorac Cardiovasc Surg. 2003;125:1070-82.

2. Mahle WT, Spray TL, Wernovsky G, Gaynor JW, Clark BJ III. Survival after reconstructive surgery for hypoplastic left heart syndrome: a 15-year experience from a single institution. Circulation. 2000;102(suppl 3):III136-41.

3. Migliavacca F, Pennati G, Dubini G, et al. Modeling of the Norwood circulation: effects of shunt size, vascular resistances, and heart rate. Am J Physiol Heart Circ Physiol. 2001;280:H2076-86.

4. Barnea O, Austin EH, Richman B, Santamore WP. Balancing the circulation: theoretic optimization of pulmonary/systemic flow ratio in hypoplastic left heart syndrome. J Am Coll Cardiol. 1994;24:1376-81.

5. Bradley SM, Atz AM, Simsic JM. Redefining the impact of oxygen and hyperventilation after the Norwood procedure. $J$ Thorac Cardiovasc Surg. 2004;127:473-80.

6. Kitaichi T, Chikugo F, Kawahito T, Hori T, Masuda Y, Kitagawa T. Suitable shunt size for regulation of pulmonary blood flow in a canine model of univentricular parallel circulations. J Thorac Cardiovasc Surg. 2003;125:71-8.

7. Charpie JR, Dekeon MK, Goldberg CS, Mosca RS, Bove EL, Kulik TJ. Postoperative hemodynamics after Norwood palliation for hypoplastic left heart syndrome. Am J Cardiol. 2001;87:198-202.

8. Hoffman GM, Ghanayem NS, Kampine JM, et al. Venous saturation and the anaerobic threshold in neonates after the Norwood procedure for hypoplastic left heart syndrome. Ann Thorac Surg. 2000;70:1515-20.

9. Maher KO, Pizarro C, Gidding SS, et al. Hemodynamic profile after the Norwood procedure with right ventricle to pulmonary artery conduit. Circulation. 2003;108:782-4.

10. Tweddell JS, Hoffman GM, Fedderly RT, et al. Phenoxybenzamine improves systemic oxygen delivery after the Norwood procedure. Ann Thorac Surg. 1999;67:161-7.

11. Hoffman GM, Tweddell JS, Ghanayem NS, et al. Alteration of the critical arteriovenous oxygen saturation relationship by sustained afterload reduction after the Norwood procedure. J Thorac Cardiovasc Surg. 2004;127:738-45. 
12. Li J, Zhang G, Holtby HM, et al. Inclusion of oxygen consumption improves the accuracy of arterial and venous oxygen saturation interpretation after the Norwood procedure. J Thorac Cardiovasc Surg. 2006;131:1099-107.

13. Taeed R, Schwartz SM, Pearl JM, et al. Unrecognized pulmonary venous desaturation early after Norwood palliation confounds Qp:Qs assessment and compromises oxygen delivery. Circulation. 2001;103: 2699-704.

14. Li J, Bush A, Schulze-Neick I, Penny DJ, Redington AN, Shekerdemian LS. Measured versus estimated oxygen consumption in ventilated patients with congenital heart disease: the validity of predictive equations. Crit Care Med. 2003;31:1235-40.

15. Li J, Hoschtitzky A, Allen ML, Elliott MJ, Redington AN. Improved balance between oxygen consumption and oxygen delivery in euthermic infants after cardiopulmonary bypass with modified ultrafiltration. Ann Thorac Surg. 2004;78:1389-96.

16. Li J, Zhang G, Holtby HM, et al. Adverse effects of dopamine on systemic hemodynamics and oxygen transport in neonates following the Norwood procedure. J Am Coll Cardiol. 2006;48:59-64.

17. Azakie T, Merklinger SL, McCrindle BW, et al. Evolving strategies and improving outcomes of the modified Norwood procedure: a 10 year single-institution experience. Ann Thorac Surg. 2001;72:1349-53.

18. De Oliveira NC, Van Arsdell GS. Practical use of alpha blockade strategy in the management of hypoplastic left heart syndrome following stage one palliation with a Blalock-Taussig shunt. Semin Thorac Cardiovasc Surg Pediatr Card Surg Annu. 2004;7:11-5.

19. Li J, Schulze-Neick I, Lincoln C, et al. Oxygen consumption after cardiopulmonary bypass surgery in children: determinants and implications. J Thorac Cardiovasc Surg. 2000;119:525-33.

20. Keidan I, Mishaly D, Berkenstadt H, Perel A. Combining low inspired oxygen and carbon dioxide during mechanical ventilation for the Norwood procedure. Paediatr Anaesth. 2003;13:58-62.

21. Mora GA, Pizarro C, Jacobs ML, Norwood WI. Experimental model of single ventricle. Influence of carbon dioxide on pulmonary vascular dynamics. Circulation. 1994;90:II43-6.
22. De Oliveira NC, Ashburn DA, Khalid F, et al. Prevention of early sudden circulatory collapse after the Norwood operation. Circulation. 2004;110(supp1 1):II133-8.

23. Li J, Hoskote A, Hickey C, VanArsdell G, Redington A, Adatia I. Hypercapnia improves systemic oxygenation and decreases oxygen consumption and blood lactate levels in children after bidirectional cavopulmonary shunt operation. Crit Care Med. 2005;33:984-9.

24. Penny DJ, Sano T, Smolich JJ. Increased systemic oxygen consumption offsets improved oxygen delivery during dobutamine infusion in newborn lambs. Intensive Care Med. 2001;27:1518-25.

25. Chiara O, Giomarelli PP, Biagioli B, Rosi R, Gattinoni L. Hypermetabolic response after hypothermic cardiopulmonary bypass. Crit Care Med. 1987; 15:995-1000.

26. Oudemans-van Straaten HM, Jansen PG, te VH, et al. Increased oxygen consumption after cardiac surgery is associated with the inflammatory response to endotoxemia. Intensive Care Med. 1996;22: 294-300.

27. Kobayashi A, Osaka T, Namba Y, Inoue S, Kimura S. Involvement of sympathetic activation and brown adipose tissue in calcitonin generelated peptide-induced heat production in the rat. Brain Res. 1999; 849:196-202.

28. Chang AC, Atz AM, Wernovsky G, Burke RP, Wessel DL. Milrinone: systemic and pulmonary hemodynamic effects in neonates after cardiac surgery. Crit Care Med. 1995;23:1907-14.

29. Wernovsky G, Wypij D, Jonas RA, et al. Postoperative course and hemodynamic profile after the arterial switch operation in neonates and infants. A comparison of low-flow cardiopulmonary bypass and circulatory arrest. Circulation. 1995;92:2226-35.

30. Scheinman MM, Brown MA, Rapaport E. Critical assessment of use of central venous oxygen saturation as a mirror of mixed venous oxygen in severely ill cardiac patients. Circulation. 1969;40:165-72.

31. Uusaro A, Ruokonen E, Takala J. Splanchnic oxygen transport after cardiac surgery: evidence for inadequate tissue perfusion after stabilization of hemodynamics. Intensive Care Med. 1996;22:26-33.

32. Archie JP Jr. Mathematic coupling of data: a common source of error. Ann Surg. 1981;193:296-303. 
TABLE E1. Clinical data for the 14 patients

\begin{tabular}{rrrrrrrrl}
\hline $\begin{array}{r}\text { Patient } \\
\text { no. }\end{array}$ & $\begin{array}{c}\text { Age } \\
(\mathbf{d})\end{array}$ & $\begin{array}{c}\text { Weight } \\
(\mathbf{k g})\end{array}$ & $\begin{array}{c}\text { BSA } \\
\left(\mathbf{m}^{2}\right)\end{array}$ & $\begin{array}{c}\text { CPB } \\
(\mathbf{m i n})\end{array}$ & $\begin{array}{c}\text { ACC } \\
(\mathbf{m i n})\end{array}$ & $\begin{array}{c}\text { Circulatory arrest } \\
(\mathbf{m i n})\end{array}$ & $\begin{array}{c}\text { Cerebral perfusion } \\
(\mathbf{m i n})\end{array}$ & \multicolumn{1}{c}{ Diagnosis } \\
\hline 1 & 7 & 3.5 & 0.23 & 108 & 47 & 12 & 35 & HLHS, AS, MS \\
2 & 4 & 3.7 & 0.25 & 151 & 100 & 35 & 53 & HLHS, AS, MS \\
3 & 7 & 4 & 0.26 & 105 & 47 & 3 & 44 & HLHS, AS, MS, \\
4 & 16 & 3.5 & 0.24 & 133 & 39 & 34 & 0 & HLHS, endocardial fibroelastosis of LV, AS, MS \\
5 & 7 & 4.2 & 0.27 & 122 & 62 & 3 & 60 & HLHS, AS, MS \\
6 & 12 & 3.5 & 0.23 & 165 & 75 & 13 & 59 & DILV, TGA \\
7 & 6 & 3.5 & 0.23 & 172 & 82 & 9 & 70 & HLHS, AA, MA, \\
8 & 16 & 3.9 & 0.25 & 170 & 60 & 1 & 60 & HLHS, AS, MS \\
9 & 7 & 4 & 0.25 & 167 & 64 & 17 & 44 & HLHS, AA, MA \\
10 & 6 & 2.9 & 0.20 & 142 & 62 & 1 & 62 & HLHS, AA, MA \\
11 & 7 & 2.8 & 0.19 & 66 & 59 & 17 & 20 & HLHS, AA MA \\
12 & 5 & 2.5 & 0.18 & 170 & 126 & 46 & 60 & HLHS, AA, MA \\
13 & 4 & 4.2 & 0.27 & 124 & 99 & 44 & 49 & HLHS, AS, MS, TAPVC \\
14 & 5 & 3.9 & 0.26 & 98 & 50 & 12 & 37 & HLHS, AA, MA \\
\hline
\end{tabular}

$B S A$, Body surface area; $C P B$, cardiopulmonary bypass; $A C C$, aortic crossclamp; HLHS, hypoplastic left heart syndrome; $A S$, aortic stenosis; $M S$, mitral stenosis; $L V$, left ventricle; DILV, double-inlet left ventricle; TGA, transposition of the great arteries; $A A$, aortic atresia; $M A$, mitral atresia; TAPVC, total abnormal pulmonary venous connection.

TABLE E2. Equations using oxygen consumption to calculate hemodynamics and oxygen transport parameters

\begin{tabular}{lr}
\hline Parameters & Equations \\
\hline Op $\left(\mathrm{L} \cdot \mathrm{min}^{-1} \cdot \mathrm{m}^{-2}\right)$ & $\mathrm{VO}_{2} /\left(\mathrm{CpvO}_{2}-\mathrm{CaO}_{2}\right)$ \\
$\mathrm{Os}\left(\mathrm{L} \cdot \mathrm{min}^{-1} \cdot \mathrm{m}^{-2}\right)$ & $\mathrm{VO}_{2} /\left(\mathrm{CaO}_{2}-\mathrm{CvO}_{2}\right)$ \\
$\mathrm{CO}\left(\mathrm{L} \cdot \mathrm{min}^{-1} \cdot \mathrm{m}^{-2}\right)$ & $0 \mathrm{~s}+\mathrm{Op}$ \\
$\mathrm{SVR}\left(\mathrm{Wood}\right.$ unit $\left.\times \mathrm{m}^{2}\right)$ & $(\mathrm{MAP}-\mathrm{MVP}) / \mathrm{Qs}$ \\
$\mathrm{BT}-\mathrm{PVR}\left(\mathrm{Wood}\right.$ unit $\left.\times \mathrm{m}^{2}\right)$ & $(\mathrm{MAP}-\mathrm{MPVP}) / \mathrm{Qp}$ \\
$\mathrm{DO}_{2}\left(\mathrm{~mL} \cdot \mathrm{min}^{-1} \cdot \mathrm{m}^{-2}\right)$ & $0 \mathrm{~s} \times \mathrm{CaO}_{2}$ \\
$\mathrm{ERO}_{2}$ & $\mathrm{VO}_{2} / \mathrm{DO}_{2}$
\end{tabular}

$\mathrm{Qp}$, Pulmonary blood flow; $\mathrm{VO}_{2}$, systemic oxygen consumption; $\mathrm{CpvO}_{2}$, pulmonary venous $\mathrm{O}_{2}$ content; $\mathrm{CaO}_{2}$, arterial (equals to pulmonary arterial) $\mathrm{O}_{2}$ content; Qs, systemic blood flow; $\mathrm{CVO}_{2}$, superior vena caval $\mathrm{O}_{2}$ content; $\mathrm{CO}$, total cardiac output; $S V R$, systemic vascular resistance; $M A P$, mean arterial pressure; $M V P$, mean superior vena caval pressure; MPVP, mean pulmonary venous mean pressure; $B T-P V R$, total pulmonary vascular resistance inclusive of the Blalock-Taussig shunt; $\mathrm{DO}_{2}$, systemic oxygen delivery; $E R \mathrm{O}_{2}$, oxygen extraction ratio. 
TABLE E3. Statistical analysis results of the changes of hemodynamics and oxygen transport in the 14 patients during the study period with mixed linear regression

\begin{tabular}{|c|c|c|c|}
\hline Variables & Intercept & Parameter estimate & $P$ values \\
\hline SVR (Wood unit $\left.\times \mathrm{m}^{2}\right)^{*}$ & 23.2 & Time -0.22 & $\begin{array}{l}.0006 \\
001\end{array}$ \\
\hline BT-PVR (Wood unit $\times \mathrm{m}^{2}$ ) & 18.1 & $\begin{array}{r}\text { Time }^{2} 0.003 \\
-0.0026\end{array}$ & $\begin{array}{l}.001 \\
.76\end{array}$ \\
\hline \multirow[t]{2}{*}{$\mathrm{CO}\left(\mathrm{L} \cdot \mathrm{min}^{-1} \cdot \mathrm{m}^{-2}\right)^{*}$} & 3.8 & Time 0.025 & .001 \\
\hline & & Time $^{2} 0.002$ & .025 \\
\hline \multirow[t]{2}{*}{ Os $\left(\mathrm{L} \cdot \mathrm{min}^{-1} \cdot \mathrm{m}^{-2}\right)^{*}$} & 1.7 & Time 0.026 & $<.0001$ \\
\hline & & Time $^{2}-0.0003$ & $<.0001$ \\
\hline Op $\left(L \cdot \min ^{-1} \cdot \mathrm{m}^{-2}\right)$ & 2.0 & 0.0057 & $<.0001$ \\
\hline Op/Os & 1.2 & 0.0008 & .45 \\
\hline $\mathrm{PaO}_{2}(\mathrm{~mm} \mathrm{Hg}) \dagger$ & 32.3 & 2.6 & $<.0001$ \\
\hline $\mathrm{SaO}_{2}(\%) \dagger$ & 69.2 & 1.9 & $<.0001$ \\
\hline $\mathrm{Hb}(\mathrm{g} / \mathrm{dL})$ & 15.2 & -0.021 & $<.0001$ \\
\hline \multirow[t]{2}{*}{$\mathrm{CaO}_{2}(\mathrm{~mL} / \mathrm{L})^{*}$} & 149.7 & Time 0.47 & .004 \\
\hline & & $\mathrm{Time}^{2} 0.007$ & .0009 \\
\hline \multirow[t]{2}{*}{$\mathrm{DO}_{2}\left(\mathrm{~mL} \cdot \mathrm{min}^{-1} \cdot \mathrm{m}^{-2}\right)^{*}$} & 242 & Time 5.1 & $<.0001$ \\
\hline & & Time $^{2}-0.07$ & $<.0001$ \\
\hline Temperature $\left({ }^{\circ} \mathrm{C}\right)$ & 36.5 & 0.001 & .27 \\
\hline $\mathrm{VO}_{2}\left(\mathrm{~mL} \cdot \mathrm{min}^{-1} \cdot \mathrm{m}^{-2}\right) \dagger$ & 99.3 & -4.4 & $<.0001$ \\
\hline \multirow[t]{2}{*}{$\mathrm{ERO}_{2}^{*}$} & 0.41 & Time -0.007 & $<.0001$ \\
\hline & & Time $^{2} 0.00009$ & $<.0001$ \\
\hline Lactate $(\mathrm{mmol} / \mathrm{L}) \dagger$ & 3.3 & -0.49 & $<.0001$ \\
\hline $\mathrm{Spvo}_{2}(\%)$ & 94.5 & 0.03 & $<.0001$ \\
\hline
\end{tabular}

$S V R$, Systemic vascular resistance; BT-PVR, total pulmonary vascular resistance including Blalock-Taussig shunt; $C O$, total cardiac output; $Q s$, systemic blood flow; $\mathrm{Qp}$, pulmonary blood flow; $\mathrm{SaO}_{2}$, arterial oxygen saturation; $\mathrm{Hb}$, hemoglobin; $\mathrm{CaO}_{2}$, arterial oxygen content; $\mathrm{DO}_{2}$, systemic oxygen delivery; $\mathrm{VO}_{2}$, systemic oxygen consumption; $\mathrm{ERO}_{2}$, oxygen extraction ratio; $\mathrm{SpvO}_{2}$, pulmonary venous oxygen saturation. *Data were entered after polynomial transformation, with time indicating the coefficient of the early trend and $t_{i m} e^{2}$ indicating the later trend. $\dagger$ Data were entered after logarithmic transformation. 
TABLE E4. Statistical analysis results of the interrelationships among the variables of hemodynamics and oxygen transport and the determinants of systemic oxygen delivery and oxygen extraction ratio in the 14 patients during the study period with mixed linear regression

\begin{tabular}{|c|c|c|c|c|}
\hline Independent variables & Dependent variable & Intercept & Parameter estimate & $P$ values \\
\hline SVR & Qp/Os ratio & 0.13 & 0.051 & $<.0001$ \\
\hline$S_{V} R^{*}$ & Os & 7.2 & -1.7 & $<.0001$ \\
\hline $\mathrm{SVR}^{*}$ & $\mathrm{CO}$ & 8.7 & -1.5 & $<.0001$ \\
\hline SVR $^{*}$ & $\mathrm{DO}_{2}$ & 989 & -233 & $<.0001$ \\
\hline BT-PVR & Op/Qs ratio & 1.54 & -0.020 & .002 \\
\hline BT-PVR* & Op & 5.1 & -1.0 & $<.0001$ \\
\hline BT-PVR & Os & 2.5 & -0.026 & .008 \\
\hline BT-PVR & $\mathrm{CO}$ & 5.7 & -0.08 & $<.0001$ \\
\hline BT-PVR & $\mathrm{DO}_{2}$ & 341 & -2.2 & .14 \\
\hline Os* & Qp/Qs ratio & 1.9 & -1.1 & $<.0001$ \\
\hline Op & Op/Qs ratio & 0.04 & 0.52 & $<.0001$ \\
\hline Qp/Os ratio* & $\mathrm{DO}_{2}$ & 321 & -193 & $<.0001$ \\
\hline Os & $\mathrm{DO}_{2}$ & 22.9 & 139 & $<.0001$ \\
\hline Qp & $\mathrm{DO}_{2}$ & 293 & 4.0 & .67 \\
\hline Qp & $\mathrm{PaO}_{2}$ & 34.6 & 2.6 & $<.0001$ \\
\hline Op & $\mathrm{SaO}_{2}$ & 66.1 & 4.2 & $<.0001$ \\
\hline $\mathrm{PaO}_{2}$ & $\mathrm{DO}_{2}$ & 117 & 4.6 & .0002 \\
\hline $\mathrm{SaO}_{2}$ & $\mathrm{DO}_{2}$ & 222 & 1.1 & .32 \\
\hline $\mathrm{Hb}$ & $\mathrm{DO}_{2}$ & 112 & 13.1 & .0008 \\
\hline \multirow[t]{4}{*}{$\mathrm{Os}+\mathrm{SaO}_{2}+\mathrm{PaO}_{2}+\mathrm{Hb}$} & $\mathrm{DO}_{2}$ & -592.42 & Os 149 & $<.0001$ \\
\hline & & & $\mathrm{SaO}_{2} 3.4$ & $<.0001$ \\
\hline & & & $\mathrm{PaO}_{2} 1.1$ & .002 \\
\hline & & & Hb 21.2 & $<.0001$ \\
\hline $\mathrm{VO}_{2}$ & $\mathrm{ERO}_{2}$ & 0.10 & 0.002 & $<.0001$ \\
\hline $\mathrm{DO}_{2}^{*}$ & $\mathrm{ERO}_{2}$ & 1.78 & -0.26 & $<.0001$ \\
\hline
\end{tabular}

Abbreviations are as indicated in Table E3. *Data were entered after logarithmic transformation for both variables being compared. 